Students of the arts and social science subjects were in greatest demand; and this was, and continues to be, reflected in the graduates emerging from universities. The proportion of those with any form of technical training remains pitifully low, and many of the developing countries are likely to state this in their papers.

Industrial patents and 'tied aid' are likely to feature prominently in the papers of Kenya, Guyana and Bangladesh. Patents are consuming an ever-increasing proportion of Third World financial resources, which is naturally resented by many. Some are likely to go so far as to say that the high cost of technology transfer is inflated through patents, trade marks and licences.

The UK Ministry of Overseas
Development (ODM) has successfully negotiated an increase in its budget by virtually promising it will use the money to buy more technology from British industry. Many developing countries are sceptical, however, one likely objection being that freedom of choice is thus restricted. As for the alternative choices, there remains little information about them in the developing world and what there is does not suffice to provide the country with the means to negotiate favourable deals in a highly competitive and complex world market.

The demand from the developing countries is for more appropriate technology. Technology itself is not enough, however; what is also essential is the 'know-how' of operation and maintenance.
It is the considered opinion of many developing countries that industrial companies are failing to reveal this information. As technology becomes more complex, so the dependence of Third World countries on outside experts increases.

Many of these charges are not being voiced for the first time. The plea for more literature has been made over a number of years. Yet many countries view UNCSTD in a favourable light; preparation for the conference has enabled them to identify and rationalise their own science policies. But UNCSTD will provide the opportunity for a meeting of minds. If the CSC can demonstrate common ground between the nations of the Commonwealth, that in itself will form a valuable contribution.

\title{
Dutch recombinant DNA guidelines to be relaxed
}

DuTCH guidelines for recombinant DNA research-based on the British and NIH guidelines-are too strict. They are to be reassessed in the light of recent research, and relaxed somewhat within the next few months.

These are some of the conclusions of the second annual report of the Dutch commission of experts concerned with the supervision of work involving genetic manipulation. The commission, formed in 1976 by the Royal Academy of Sciences on the request of the ministers for education and sciences and science policy, pays great attention in the report to recent developments in assessing the hypothetical risks of recombinant DNA research.

The commission, in line with opinion outside the Netherlands, considers it very important to have uniform international guidelines for experiments with recombinant DNA to avoid national differences which would lead to unequal opportunities for researchers of different nationalities. In its report, the commission reaffirms its recommendations to the previous government last year to establish legislation for recombinant DNA research.

Last August, the then minister for health and environmental protection instructed the commission to exercise the utmost caution in coming up with its recommendations. Many thought this indicated a call for a ban on recombinant DNA research, but since then the commission has continued with its work as before. Now 11 projects-all in the NIH P1 category or the Williams' report category I-are going on at three universities (at the end of 1976 there was only one project). In 197730 proposals were assessed (against nine in 1976) in eight laboratories within five universities.
Industry has plans to become involved but has not begun experiments yet.

The new government, in a statement issued to coincide with the publication of the report, said that research in the two lowest categorics can continue --but only if done under the commission's supervision. Supervision, as in the UK, is on the basis of gentlemen's agreements with universities and institutes.

Earlier this month a public discus-

\section{Ariane heads south}

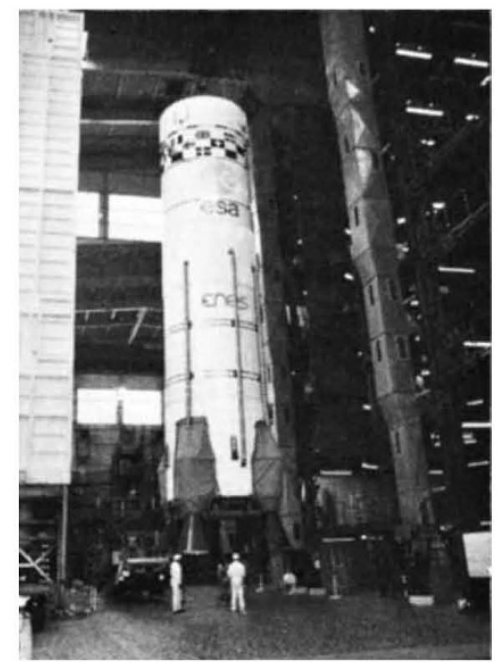

A FULL-SCALE model of the fuel assemblies of Ariane, the European Space Agency's satellite launcher currently under development by the French Centre National d'Etudes Spatiales (CNES), left Le Havre for the launch base at Kourou in French Guiana last week. As soon as the model is in position on the launch pad, the CNES will begin testing it for sion was held in Holland with the purpose of informing politicians and members of local and regional governments of the issues associated with recombinant DNA research. About 500 people attended, most of them being scientists, trade unionists and politicians. It was the first time that $d$ forum with the aim of airing a scientific matter in public had been held in Holland.

Casper Schurring

compatibility with facilities at the pad-such as the platform and towerand for correct functioning. Aerospatiale, the "system integrator," will assess the flight behaviour of the launcher in the local climatic conditions and the effect of vibration during lift-off.

By the beginning of next year, development of all stages and components should be complete. The first qualification launch, which will carry ballast as its payload as well as equipment to measure flight characteristics, is scheduled for June 1979. The subsequent three qualification flights, which will be launched before October 1980, however, will be used to put several satellites into orbit.

Production of the first five operational Arianes was agreed by the ESA member states earlier this year at a total cost of $163 \mathrm{~m}$ AU (1 $\mathrm{AU}=$ £0.67). Three will be used to launch ESA's Exosat, Marots-B and ECS-1 satellites in 1981. They will be financed out of the relevant ESA programmes. Onc, which will launch the French Earth observation satellite SPOT will be paid for by France. And the fifth will be kept in reserve and funded by ESA until a payload can be found for it. 